\title{
First time intravesically administered trifunctional antibody catumaxomab in patients with recurrent non-muscle invasive bladder cancer indicates high tolerability and local immunological activity
}

\author{
Peter Ruf $^{1}$ D $\cdot$ Hartwig W. Bauer ${ }^{2} \cdot$ Alexandra Schoberth $^{1,3} \cdot$ Claudia Kellermann $^{1} \cdot$ Horst Lindhofer $^{1}$
}

Received: 11 November 2020 / Accepted: 26 March 2021 / Published online: 10 April 2021

(c) The Author(s) 2021

\begin{abstract}
Transurethral resection of the tumor (TUR-B) followed by adjuvant intravesical treatment with cytostatic drugs or Bacillus Calmette-Guérin (BCG) as standard therapy of non-muscle-invasive bladder cancer (NMIBC) is associated with a high recurrence rate of about $60-70 \%$, considerable side effects and requires close monitoring. Alternative treatment options are warranted. Two patients with epithelial cell adhesion molecule (EpCAM)-positive recurrent non-muscle invasive bladder cancer were treated the first time by an intravesical administration of the trifunctional bispecific EpCAM targeting antibody catumaxomab (total dosage of 470 and $1120 \mu \mathrm{g}$, respectively). The binding and killing activity of catumaxomab in urine milieu was evaluated in vitro. In contrast to its previous systemic application catumaxomab was well tolerated without any obvious signs of toxicity. Relevant cytokine plasma levels were not detected and no significant systemic drug release was observed. The induction of a human anti-mouse-antibody (HAMA) reaction was either absent or untypically weak contrary to the high immunogenicity of intraperitoneal applied catumaxomab. Tumor cells that were detectable in urine patient samples disappeared after catumaxomab therapy. Endoscopically confirmed recurrence-free intervals were 32 and 25 months. Our data suggest that intravesical administration of catumaxomab in NMIBC is feasible, safe and efficacious, thus arguing for further clinical development of catumaxomab in this indication.
\end{abstract}

Keywords Adjuvant intravesical treatment $\cdot$ Epithelial cell adhesion molecule (EpCAM) - Recurrence-free intervals . Intravesical administration of Catumaxomab antibody $\cdot$ Recurrent non-muscle-invasive bladder cancer $\cdot$ Trifunctional antibody

$\begin{array}{ll}\text { Abbreviations } \\ \text { BCG } & \text { Bacillus Calmette-Guérin } \\ \text { EpCAM } & \text { Epithelial cell adhesion molecule } \\ \text { HAMA } & \text { Human anti-mouse-antibody } \\ \text { i.p. } & \text { Intraperitoneal } \\ \text { NMIBC } & \text { Non-muscle-invasive bladder cancer } \\ \text { PBMC } & \text { Peripheral blood mononuclear cells } \\ \text { TCC } & \text { Transitional cell carcinoma } \\ \text { TUR-B } & \text { Transurethral resection of the tumor }\end{array}$

Peter Ruf

peter.ruf@trionresearch.de

1 Trion Research GmbH, Am Klopferspitz 19, 82152 Martinsried, Germany

2 Urologie Maximilianstrasse, Maximilianstrasse 31, 80539 München, Germany

3 Freeline Therapeutics GmbH, Semmelweisstrasse 3, 82152 Martinsried, Germany

\section{Introduction}

Bladder cancer is the 9th leading cancer entity worldwide with 430,000 new cases and about 165,000 deaths occurring yearly [1]. More than $90 \%$ of patients with bladder cancer have urothelial or transitional cell carcinoma (TCC) and the majority of cases (approximately 75\%) are non-muscleinvasive (stages CIS, Ta [papillary tumor] or T1) [2]. The standard therapy of non-muscle-invasive bladder cancer (NMIBC) comprises transurethral resection of the tumor (TUR-B) followed by adjuvant intravesical treatment with cytostatic drugs or Bacillus Calmette-Guérin (BCG). However, the overall recurrence rate is high and about $60-70 \%$ of patients relapse, which requires close monitoring and continuous treatment [3]. Besides, the most effective BCG therapy causes considerable side effects in $8-20 \%$ of patients and the treatment has to be suspended due to intolerance $[4$, 5]. Thus, alternative treatment modalities for NMIBC are warranted. 
The epithelial cell adhesion molecule EpCAM is expressed in many cancer tissues including TCC $[6,7]$. Successful EpCAM-targeted immunotherapy has already been demonstrated using the antibody catumaxomab, which obtained EMA approval in 2009 for the intraperitoneal treatment of malignant ascites [8], that was-however-withdrawn in 2017 for commercial reasons. Catumaxomab is an intact trifunctional bispecific antibody that targets EpCAM and the T-cell antigen CD3. Additionally, the antibody binds and activates Fc $\gamma$ R-positive accessory immune cells via its chimeric rat/mouse Fc portion $[9,10]$. Consequently, EpCAM-positive cancer cells are highly efficiently killed by catumaxomab, which induces a concerted attack of $\mathrm{T}$ cells and accessory immune cells like monocytes, dendritic cells and NK-cells and thereby even elicits a vaccination effect $[11,12]$.

Although EpCAM is expressed in healthy urothelium [13], its accessibility is shielded by the glycosaminoglycan layer (GAG) that covers the luminal surface of the urothelium $[14,15]$. Thus, specific uptake of the radiolabeled antiEpCAM mouse antibody AUA1 was only shown in transitional cell carcinoma but not in healthy urothelial tissue in a biodistribution study when the antibody was administered intravesically [15]. Importantly, in this study only unremarkable antibody levels were detected in blood. Therefore, we reasoned that the intravesical route of application should prevent significant systemic exposure to catumaxomab resulting in an improved tolerability. Based on its local tumor specificity, intravesically administered catumaxomab might represent a new immunotherapeutic approach for the treatment of recurrent NMIBC. For verification of this hypothesis, we first evaluated the binding and killing activity of catumaxomab to immune and bladder cancer cells in urine milieu in vitro. Finally, two patients with recurrent NMIBC were individually treated with intravesically administered catumaxomab. Tolerability, systemic antibody exposure, human anti-mouse-antibody (HAMA) induction, cytokine plasma levels and tumor cell count in urine samples were monitored and frequent endoscopic re-evaluations were performed.

\section{Materials and methods}

\section{Patients and treatment}

Patients were individually treated with catumaxomab (LINDIS Biotech, Martinsried, Germany) on a named-patient basis at the urology practice Urologie Maximilianstraße (Munich, Germany) after obtaining written informed consent. Catumaxomab was administered to the empty bladder by a transurethral catheter in $40 \mathrm{ml}$ PBS solution ( $\mathrm{pH}$ 7.4) and held for at least two hours before voiding to allow binding of the antibody. One treatment cycle comprised six to seven weekly instillations with increasing antibody dosages between 20 and $100 \mu \mathrm{g}$. The dosage was chosen according to the experience gained from intraperitoneal usage of catumaxomab where the maximum tolerated dose (MTD) was defined at 10-20-50 and $200 \mu \mathrm{g}$ [30]. This dosage approach was further justified considering the lower permeability of the bladder wall in comparison to the peritoneum and the short exposure time of only $2 \mathrm{~h}$ after which the drug is voided again.

\section{Evaluation of in vitro antibody binding and killing activity in urine milieu}

Antibody binding was evaluated by flow cytometry. $5 \times 10^{5}$ target cells were incubated at $2-8{ }^{\circ} \mathrm{C}$ for $60 \mathrm{~min}$ at the indicated catumaxomab concentrations. To analyze the trifunctional binding of catumaxomab different target cells were used: Jurkat cells (ATCC, USA) for binding to CD3, BFTC-905 bladder cancer cells [16] (DSMZ, Germany) for binding to EpCAM, and the monocytic cell line THP-1 (ATCC, USA) that expresses Fc $\gamma$ RI and IIa. $5 \times 10^{6}$ target cells per $\mathrm{ml}$ were resuspended in either PBS buffer or urine samples of healthy donors at final concentrations of 10 and $90 \%$ vol. Then, cells were washed two times and cell-bound catumaxomab was detected with $\mathrm{F}\left(\mathrm{ab}^{\prime}\right)$ 2-rat-anti-mouse $\mathrm{IgG}$ $(\mathrm{H}+\mathrm{L})$-FITC (Jurkat cells) or mouse-anti-rat $\mathrm{IgG}(\mathrm{H}+\mathrm{L})$ FITC (BFTC-905 cells), or F(ab')2-goat-anti-rat IgG -FITC (THP-1 cells) (Jackson Immuno Research, USA). Stained cells were detected using a FACS-Calibur cytometer (Becton Dickinson, USA).

Catumaxomab-mediated killing of EpCAM-positive BFTC-905 bladder cancer cells was evaluated in an allogeneic cytotoxicity assay [9]. Thereby, the "killing activity" of catumaxomab in PBS buffer control was compared to its activity in samples containing $10 \%$ vol urine. Urine samples from each three different male and female donors were tested and freshly prepared PBMC of the same donor were mixed with BFTC 905 tumor cells and the indicated catumaxomab amounts. The effector to target ratio was 5:1. Graph Pad Prism software (Version 5.04) was used for graphical visualization and dose-response curve presentation. Nonlinear asymmetric five-parameter curve fitting was applied and $\mathrm{EC}_{50}$, top and bottom values and their corresponding $95 \%$ confidence intervals were calculated. Goodness of fit as determined by $\mathrm{R}$ square was in all cases $>0.98$. Outliers are presented in the corresponding figures.

\section{Detection and quantification of tumor cells in patient urine samples}

Midstream urine samples of the patients were analyzed for EpCAM-positive tumor cells before and after the treatment. EpCAM-positive tumor cells were detected by an established 
and described immunocytochemistry protocol [17]. Briefly, cells in $30 \mathrm{ml}$ urine were centrifuged on cytospins. Slides were double-stained for EpCAM and cytokeratin. EpCAM staining was performed with the EpCAM-specific antibody HO-3 [18] directly labeled with Alexa Fluor 594 Texas Red. For cytokeratin staining the anti-cytokeratin $8,18,19$ antibody A45B-B3 together with the corresponding Alexa Fluor 488-labeled secondary anti-mouse IgG1 detection antibody (Molecular Probes, USA) were used. All cytospins were analyzed by a computerized image analysis system (MDS, Applied Imaging) counting double stained cells.

\section{HAMA response, cytokine measurement and systemic catumaxomab detection}

HAMA (human anti-mouse antibodies) were quantified by using the medac ELISA kit (medac, Hamburg, Germany) following the instructions of the manufacturer. Concentrations below $40 \mathrm{ng} / \mathrm{ml}$ are considered as negative. Cytokine levels in plasma samples were analyzed by using the Luminex system 200 (Luminex, TX, USA) together with the premixed 8-plex fluorokine X-Map kit (R\&D Systems, MN, USA) comprising the cytokines IL-2, IL-4, IL-6, IL-8, IL-10, IL-17, IFN- $\gamma$ and TNF. Samples were collected at the indicated time points, stored at $-20{ }^{\circ} \mathrm{C}$ and measured in batch. Samples collected on treatment days were taken before antibody instillation and $24 \mathrm{~h}$ later. The detection limit of cytokines was $3.2 \mathrm{pg} / \mathrm{ml}$. Systemic catumaxomab concentrations were measured by ELISA as described previously [19]. The quantification limit of the ELISA method is $125 \mathrm{pg} / \mathrm{ml}$.

\section{Results}

\section{Binding and cytotoxic activity of catumaxomab in urine milieu}

Catumaxomab was able to effectively bind to all of its target antigens even in the presence of $90 \%$ vol urine (Fig. 1a, b, c). A significant decrease in binding was mainly observed at low antibody concentrations of $0.1 \mu \mathrm{g} / \mathrm{ml}$, whereas at intermediate $(1 \mu \mathrm{g} / \mathrm{ml})$ and at saturating antibody concentrations $(10 \mu \mathrm{g} / \mathrm{ml})$ the diminishing effect was less pronounced or even absent. There was no difference between urine samples from male or from female donors despite different mean $\mathrm{pH}$ values (pH 5.3 (male) versus pH 6.7 (female), data not shown).

Catumaxomab-induced cytotoxic activity against bladder cancer cells was tested in a urine milieu of $10 \%$ vol. (three urine samples of different male and female healthy donors). Catumaxomab maintained its killing activity in the presence of urine samples and no sex-related difference was observed
(Fig. 2). The cytotoxic activity of catumaxomab was comparable to buffer control $\left(\mathrm{EC}_{50}=0.16 \mathrm{ng} / \mathrm{ml}\right)$ or even more effective in urine samples with $\mathrm{EC}_{50}$ values ranging between $0.03 \mathrm{ng} / \mathrm{ml}$ and $0.15 \mathrm{ng} / \mathrm{ml}$.

\section{Treatment results of patient 1}

The first patient was a 70 years old woman with urothelial cell carcinoma (pTa, G2) initially diagnosed in 2004 . Between 2005 and 2015, she was suffering from five local recurrences (pTa, G1, singular and monolocular) which could be removed by TUR-B. After a further tumor recurrence in 2015 , the patient denied the TUR-B for personal reasons. Having confirmed EpCAM-positive tumor cells she was treated with six doses of catumaxomab starting with $20 \mu \mathrm{g}$ up to $100 \mu \mathrm{g}$ (total amount of antibody $470 \mu \mathrm{g}$ ).

The antibody was well tolerated without adverse events such as fever or flu-like symptoms which correlated with low systemic cytokine levels, which are in contrast elevated when catumaxomab was administered intraperitoneally [20] or intravenously [21]: No IL-2, IL-4, IL-10, IL-17 or IFN- $\gamma$ was traceable in plasma (Table 1). Only very low and transient amounts of IL-6 (10-13 pg/ml) were measured after the first and second instillation. Plasma concentrations of catumaxomab remained below the quantification limit of $125 \mathrm{pg} /$ $\mathrm{ml}$. Induction of human anti-mouse antibodies (HAMA) did not occur up to 14 days after the end of the antibody therapy (Table 1).

The number of EpCAM-positive tumor cells dropped from 23 to 0,14 days after the last instillation and followup samples were still negative for tumor cells until day 701 with the exception of day 631 where one tumor cell was found (Table 1). Endoscopic imaging of the bladder confirmed this finding. A growing papillary structure, typical for superficial bladder cancer, was imaged two weeks before the start of catumaxomab treatment and was not detectable two weeks after the last catumaxomab application. Apart from a slight inflammation the mucosa appeared completely normal (Fig. 3). The patient remained relapse-free confirmed by cystoscopy and urine cytology every three months. Last follow-up visit was at 32 months. Further regular control visits were not possible due to occurring dementia. A last contact, 45 months after treatment showed inconspicuous urine cytology with now signs of microhematuria.

\section{Treatment results of patient 2}

A 72 years old man with urothelial cell carcinoma (pTa, G2) that was first diagnosed in June 2004 and in October 2014 a papillary growing neoplasia with positive FISH-test and dysplastic urothelial cells was detected during an endoscopic control visit. Because of several cardiovascular and other comorbidities (hepatopathy) a proposed TUR-B was refused 
Fig. 1 Trifunctional binding activity of catumaxomab in urine samples. Binding of catumaxomab to the bladder carcinoma cell line BFTC-905 (a), to CD3-positive Jurkat cells (b), or to Fc $\gamma$ RI/IIa expressing THP-1 cells (c) at concentrations of $0.1,1.0$, and $10 \mu \mathrm{g} / \mathrm{ml}$ and in the presence of different urine amounts $(0,10,90 \%$ volume $)$ is shown. Each column represents the mean value of six individual measurements (means of double determinations) with urine samples of three healthy male and three healthy female donors. Error bars indicate standard deviation. Asterisks show significant differences between $0 \%$ and other urine groups (t-test, $* p \leq 0.05 ; * * p \leq 0.01$; $* * * p \leq 0.001)$. MFI = mean fluorescence intensity. On the right hand side, flow cytometry overlays of binding results from one representative donor at $10 \%$ urine concentration are included. Different colors indicate cell binding at $10 \mu \mathrm{g} /$ $\mathrm{ml}$ (green line), $1 \mu \mathrm{g} / \mathrm{ml}$ (blue line), or $0.1 \mu \mathrm{g} / \mathrm{ml}$ (orange line) catumaxomab concentration.

The filled purple histogram represents the negative control without catumaxomab, but secondary detection antibody only
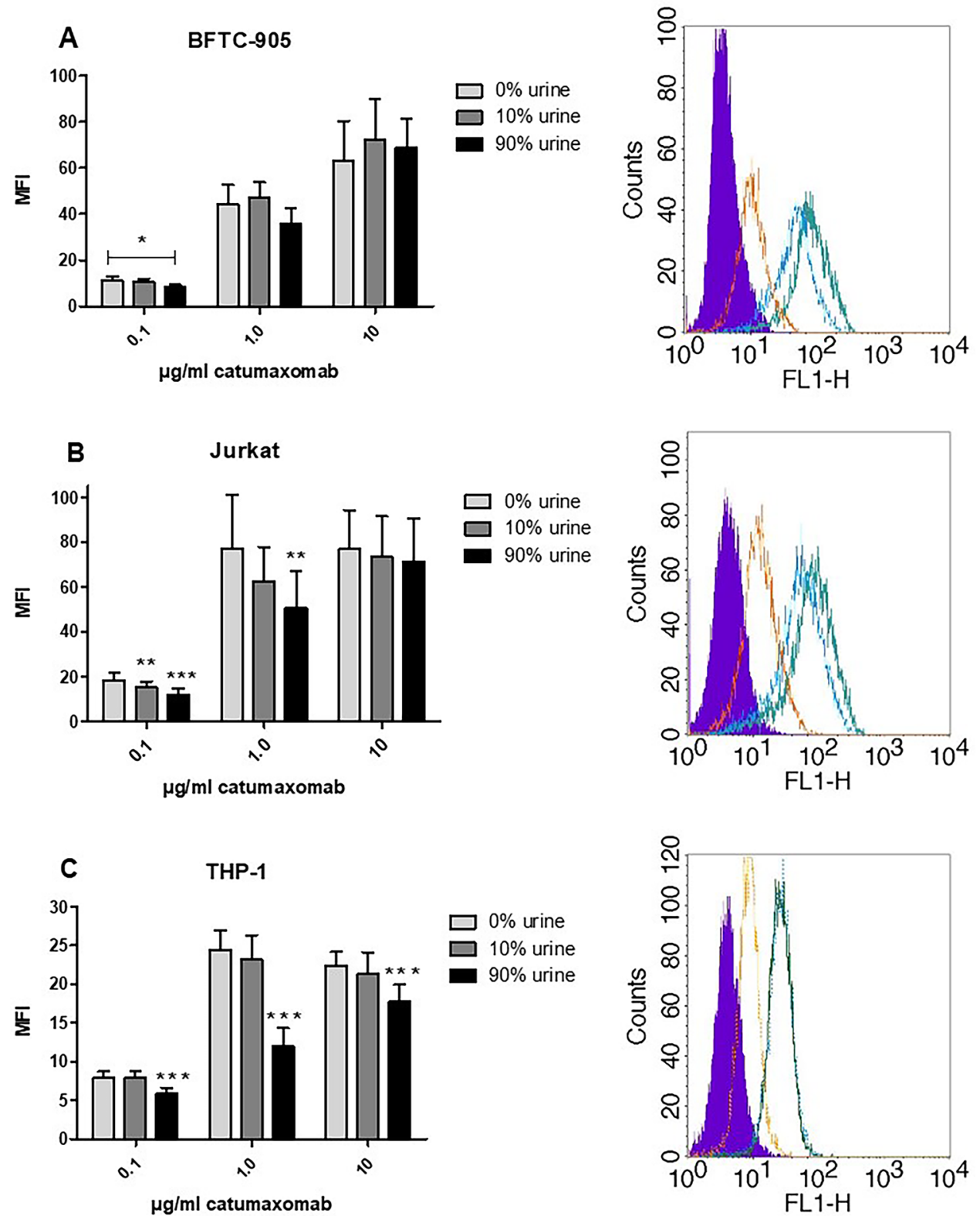

by the patient. Alternatively, a first treatment cycle with six weekly, intravesically administered doses of catumaxomab antibody was started in March 2015. Urine cytology displayed various urothelial cells with enlarged, hyperchromatic cell nuclei and a nucleus/plasma ratio changed in favor of the cell nuclei. Ten days after treatment no atypical cells were observed. Endoscopic follow-up controls and urine cytology remained negative for approximately six months. An unclear inflammatory change of the bladder mucosa with a positive Urovysion test (Abbott) implicated a relapse afterwards. The patient received a second treatment cycle consisting of seven weekly instillations of $1 \times 50$ and $6 \times 100 \mu \mathrm{g}$ of catumaxomab. EpCAM-positive tumor cells were detectable in the urine but continuously dropped from 111 to 0,52 days after the last instillation of the second treatment cycle (Table 2). Eleven tumor cells were found at day 770 but endoscopic controls every three months remained inconspicuous for a follow-up period of 25 months. After 36 months the patient progressed with a diagnosed, histopathologic confirmed urothelial cell carcinoma in the right renal pelvis. In view of several comorbidities an operative treatment was not performed and the patient died shortly after diagnosis due to cardiovascular complications.

Catumaxomab treatment was well tolerated without signs of fever, inflammation or cytokine-induced side effects. Apart from an intermediate detection of IL-6 (16$13 \mathrm{pg} / \mathrm{ml}$ ) no cytokines were detected (Table 2). Catumaxomab slightly above the quantification limit of $125 \mathrm{pg} /$ 
A

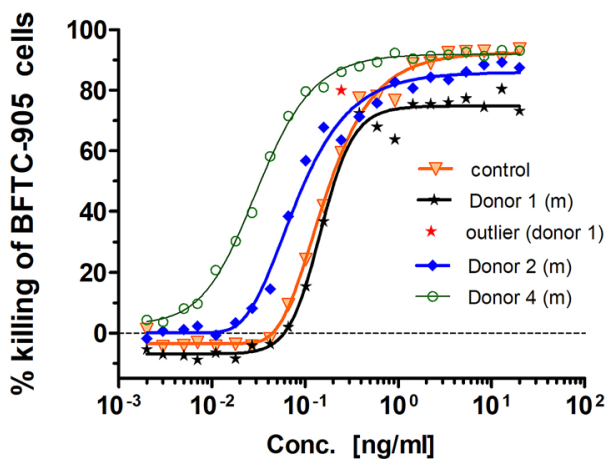

Fig. 2 Biological anti-tumor activity of catumaxomab in urine samples. No negative influence was observed on catumaxomab mediated killing of targeted bladder cancer cells BFTC-905 after the addition of $10 \%$ vol urine. Each three different urine samples from healthy male (a) and female donors (b) were tested and compared
B

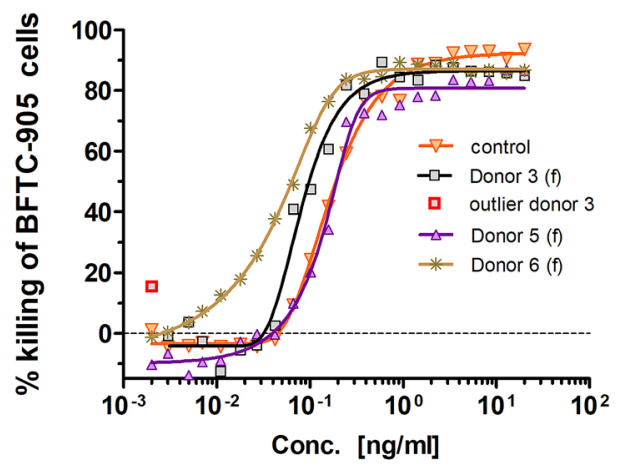

to buffer control (PBS). 22 different antibody concentrations ranging from $20 \mathrm{ng} / \mathrm{ml}$ to $0.002 \mathrm{ng} / \mathrm{ml}$ were applied and resulting dose response curves are displayed. Mean results of double determinations are shown; Calculated $\mathrm{EC}_{50}$ values ranged from 0.03 to $0.15 \mathrm{ng} / \mathrm{ml}$ (buffer control $0.16 \mathrm{ng} / \mathrm{ml}$ )

Table 1 Immunomonitoring results of patient 1

\begin{tabular}{|c|c|c|c|c|c|c|c|c|}
\hline Day & $\begin{array}{l}\text { Catumax- } \\
\text { omab }(\mu \mathrm{g})\end{array}$ & $\begin{array}{l}\text { IL-2, 4, 10, } 17 \\
\text { IFN- } \gamma^{\S}(\mathrm{pg} / \mathrm{ml})\end{array}$ & IL-6 (pg/ml $)^{\S}$ & IL-8 (pg/ml) $)^{\S}$ & $\mathrm{TNF}(\mathrm{pg} / \mathrm{ml})^{\S}$ & $\begin{array}{l}\text { Systemic Catu } \\
(\mathrm{pg} / \mathrm{ml})^{*}\end{array}$ & HAMA $^{+}$ & $\begin{array}{l}\text { Number } \\
\text { of tumor } \\
\text { cells }^{\#}\end{array}$ \\
\hline 0 & 20 & $<3.2$ & $<3.2$ & 8 & 7 & $<125$ & Neg & 23 \\
\hline 1 & & $<3.2$ & $<3.2$ & 9 & 6 & $<125$ & & \\
\hline 7 & 50 & & & & & & & \\
\hline 8 & & $<3.2$ & 13 & $<3.2$ & $<3.2$ & $<125$ & & \\
\hline 14 & 100 & $<3.2$ & 10 & $<3.2$ & $<3.2$ & $<125$ & $\mathrm{Neg}$ & \\
\hline 21 & 100 & & & & & & & \\
\hline 22 & & $<3.2$ & $<3.2$ & $<3.2$ & $<3.2$ & $<125$ & & \\
\hline 28 & 100 & $<3.2$ & $<3.2$ & $<3.2$ & $<3.2$ & $<125$ & $\mathrm{Neg}$ & \\
\hline 29 & & $<3.2$ & $<3.2$ & $<3.2$ & $<3.2$ & $<125$ & & \\
\hline 35 & 100 & $<3.2$ & $<3.2$ & $<3.2$ & $<3.2$ & $<125$ & $\mathrm{Neg}$ & 12 \\
\hline 36 & & $<3.2$ & $<3.2$ & $<3.2$ & $<3.2$ & $<125$ & & \\
\hline 49 & & $<3.2$ & $<3.2$ & $<3.2$ & $<3.2$ & $<125$ & Neg & 0 \\
\hline 148 & & & & & & & & 0 \\
\hline 211 & & & & & & & & 0 \\
\hline 339 & & & & & & & & 0 \\
\hline 456 & & & & & & & & 0 \\
\hline 631 & & & & & & & & 1 \\
\hline 701 & & & & & & & & 0 \\
\hline
\end{tabular}

*Lower limit of quantification for plasma samples $=125 \mathrm{pg} / \mathrm{ml}$

$\S$ Detection limit of cytokines in plasma samples $=3.2 \mathrm{pg} / \mathrm{ml}$

+ Values below $40 \mathrm{ng} / \mathrm{ml}$ are considered negative;

\# $30 \mathrm{ml}$ urine samples were analyzed 
Fig. 3 Endoscopic evaluation before and after catumaxomab treatment. Endoscopic images of the bladder of patient 1 at different magnifications two weeks before $(\mathbf{a}, \mathbf{b})$ and two weeks after $(\mathbf{c}-\mathbf{f})$ treatment with catumaxomab are shown. Arrow in $\mathrm{B}$ points to a growing papillary structure that disappeared after one treatment cycle with catumaxomab $(\mathbf{c}-\mathbf{f})$
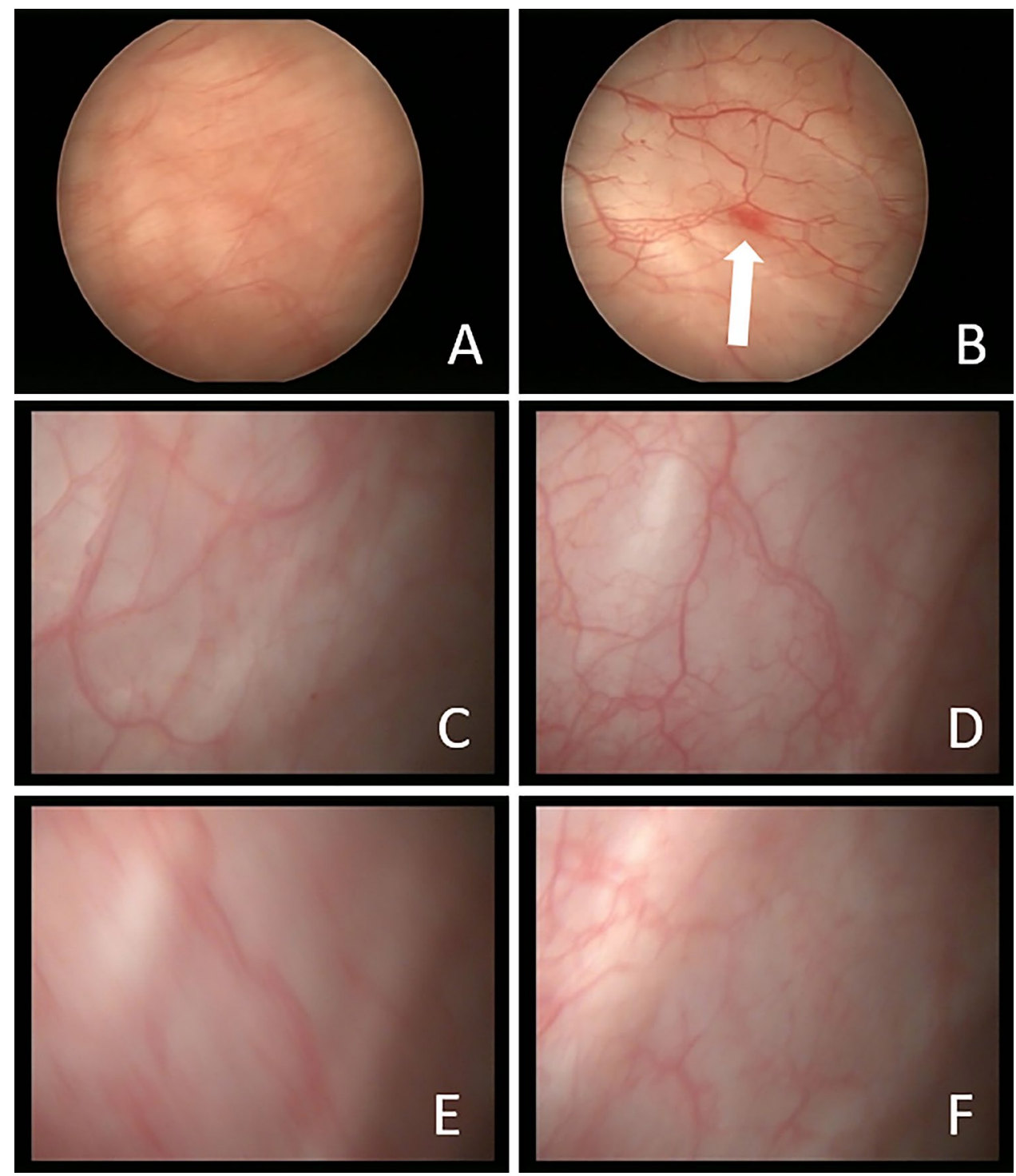

$\mathrm{ml}$ was traceable in plasma after the second and the fifth application and low HAMA levels were measured during the first and second treatment cycles (Table 2).

\section{Discussion}

In spite of new treatment options like PD-1/PD-L1 checkpoint inhibitors [22-24], advanced and metastasized bladder cancer remains a fatal disease. Fortunately, a majority of about $75 \%$ of diagnosed bladder cancers is local and nonmuscle-invasive [25]. Following TUR-B, recommended prophylactic and maintenance BCG therapy [26-28] is associated with severe and painful inflammation-caused side effects and about $8-20 \%$ of patients suspend the treatment $[4,5]$ and $30-40 \%$ of patients do not respond to the therapy [29]. For BCG-refractory, -unresponsive or -intolerant patients radical cystectomy often represents the ultima ratio. impacting the quality of life.

Due to its expression pattern in TCC, EpCAM is a clinically relevant antigen target for immunotherapy of bladder cancer $[6,7]$. In an in vitro urinary environment catumaxomab showed a robust binding to all three target antigens or receptors, respectively (EpCAM, CD3 and Fc $\gamma$ RI/IIa; Fig. 1). Inhibitory effects of urine were mainly seen at lower antibody concentrations $(<1 \mu \mathrm{g} / \mathrm{ml})$ and were compensated by the application of higher local antibody amounts. In accordance with the binding results, catumaxomab-induced cytotoxicity against EpCAM-positive bladder cancer cells was not diminished in 10\% vol. urine samples (Fig. 2). Higher urine concentrations might also be tolerable but could not be tested because of the disturbing influence of the urine itself on the growth of the tumor cells. These nonclinical results suggest that catumaxomab might indeed be 
Table 2 Immunomonitoring results of patient 2

\begin{tabular}{|c|c|c|c|c|c|c|c|c|}
\hline Day & $\begin{array}{l}\text { Catumax- } \\
\text { omab }(\mu \mathrm{g})\end{array}$ & $\begin{array}{l}\text { IL-2, 4, 10, } 17 \\
\text { IFN- } \gamma^{\S}(\mathrm{pg} / \mathrm{ml})\end{array}$ & IL-6 (pg/ml) $\S$ & IL-8 $(\mathrm{pg} / \mathrm{ml})^{\S}$ & $\mathrm{TNF}(\mathrm{pg} / \mathrm{ml})^{\S}$ & $\begin{array}{l}\text { Systemic } \\
\text { Catu (pg/ } \\
\mathrm{ml})^{*}\end{array}$ & HAMA $^{+}$ & Number of tumor cells \# \\
\hline \multicolumn{9}{|c|}{ First treatment cycle } \\
\hline 0 & 20 & $<3.2$ & $<3.2$ & 9 & 9 & $<125$ & 40 & Not evaluable** \\
\hline 7 & 50 & $<3.2$ & $<3.2$ & 8 & 7 & $<125$ & 67 & \\
\hline 8 & & $<3.2$ & $<3.2$ & 10 & 7 & 214 & & \\
\hline 14 & 100 & & & & & 162 & & \\
\hline 15 & & $<3.2$ & 16 & 9 & $<3.2$ & & & \\
\hline 21 & 100 & $<3.2$ & 13 & 9 & $<3.2$ & $<125$ & 198 & \\
\hline 22 & & $<3.2$ & 13 & 10 & $<3.2$ & $<125$ & & \\
\hline 28 & 100 & $<3.2$ & $<3.2$ & $<3.2$ & $<3.2$ & $<125$ & 163 & \\
\hline 29 & & $<3.2$ & $<3.2$ & $<3.2$ & $<3.2$ & 170 & & \\
\hline 35 & 100 & $<3.2$ & $<3.2$ & $<3.2$ & $<3.2$ & $<125$ & 60 & Not evaluable** \\
\hline 36 & & $<3.2$ & $<3.2$ & $<3.2$ & $<3.2$ & $<125$ & & Not evaluable** \\
\hline \multicolumn{9}{|c|}{ Second treatment cycle } \\
\hline 225 & 50 & $<3.2$ & $<3.2$ & $<3.2$ & $<3.2$ & $<125$ & 159 & \\
\hline 226 & & $<3.2$ & $<3.2$ & $<3.2$ & $<3.2$ & $<125$ & & 111 \\
\hline 232 & 100 & $<3.2$ & $<3.2$ & $<3.2$ & $<3.2$ & $<125$ & 63 & \\
\hline 233 & & $<3.2$ & $<3.2$ & $<3.2$ & $<3.2$ & $<125$ & & 83 \\
\hline 239 & 100 & $<3.2$ & $<3.2$ & $<3.2$ & $<3.2$ & $<125$ & 63 & \\
\hline 240 & & $<3.2$ & $<3.2$ & $<3.2$ & $<3.2$ & $<125$ & & 26 \\
\hline 246 & 100 & $<3.2$ & $<3.2$ & $<3.2$ & $<3.2$ & $<125$ & 64 & \\
\hline 247 & & $<3.2$ & $<3.2$ & $<3.2$ & $<3.2$ & $<125$ & & 27 \\
\hline 253 & 100 & $<3.2$ & $<3.2$ & $<3.2$ & $<3.2$ & $<125$ & 154 & \\
\hline 254 & & $<3.2$ & $<3.2$ & $<3.2$ & $<3.2$ & $<125$ & & 8 \\
\hline 260 & 100 & $<3.2$ & $<3.2$ & $<3.2$ & $<3.2$ & $<125$ & 281 & \\
\hline 261 & & $<3.2$ & $<3.2$ & $<3.2$ & $<3.2$ & $<125$ & & 6 \\
\hline 267 & 100 & $<3.2$ & $<3.2$ & $<3.2$ & $<3.2$ & $<125$ & & \\
\hline 268 & & $<3.2$ & $<3.2$ & $<3.2$ & $<3.2$ & $<125$ & & 4 \\
\hline 319 & & & & & & & & 0 \\
\hline 464 & & & & & & & & 0 \\
\hline 770 & & & & & & & & 11 \\
\hline
\end{tabular}

*Lower limit of quantification for plasma samples $=125 \mathrm{pg} / \mathrm{ml}$

+ Values below $40 \mathrm{ng} / \mathrm{ml}$ are considered negative

\# $30 \mathrm{ml}$ urine samples were analyzed;

** samples not evaluable due to high cell debris background

${ }^{\S}$ Detection limit of cytokines in plasma samples $=3.2 \mathrm{pg} / \mathrm{ml}$

immunologically active in the bladder of cancer patients assuming that sufficient immune effector cells are present. Potentially recruited effector cells may derive from the urinary fluid or from immune cells infiltrating the tumor lesions. By virtue of its trifunctional mode of action catumaxomab strongly activates not only $\mathrm{T}$ cells but also accessory immune cells which may lead to the recruitment of additional effector cells as shown previously for malignant ascites [17].
This hypothesis was tested in two individuals with a history of recurrent NMIBC who denied further TUR-B for personal and medicinal reasons.

After intravesical administration of catumaxomab no EpCAM-positive tumor cells were found any more in the urine after one, respectively two treatment cycles (Tables 1 and 2). In one patient, the dissolving of a neoplastic, papillary structure could be confirmed by endoscopic imaging (Fig. 3). Follow-up endoscopic re-evaluations every three months confirmed an ongoing recurrence-free interval of 32 and 25 months. These data indicate that catumaxomab 
might be clinically effective and safe in the treatment of recurrent NMIBC.

Total amounts of $470 \mu \mathrm{g}$ and $1120 \mu \mathrm{g}$ catumaxomab, respectively, could be applied without any signs of toxicity in contrast to i.p. administered catumaxomab. where the maximum tolerated dose (MTD) was found at 10-20-50 and $200 \mu \mathrm{g}$ [30]. The predominant catumaxomab-induced side effects like fever, chills, headache and vomiting are mediated by the release of cytokines [30]. No relevant cytokine levels could be detected in the plasma of the patients (Tables 1 and 2) indicating no systemic distribution of catumaxomab after instillation into the bladder. Accordingly, the lack of HAMA development may allow the repeated application of the drug without loss of efficacy. This was demonstrated for patient 2 who received a second treatment cycle and thereafter showed a complete elimination of EpCAM-positive tumor cells in the urine.

In conclusion, the intravesical application of catumaxomab in two patients with recurrent NMIBC was feasible and safe and demonstrated first signs of efficacy. Therefore, a phase I clinical study has been started to investigate safety and tolerability of intravesically applied catumaxomab in patients with high risk NMIBC (Eudract: 2019-002,850-22). For further clinical development also combination treatments of catumaxomab and BCG or immune checkpoint inhibitors have to be considered.

Acknowledgements The authors would like to thank Susanne Hirschberger in the department of antibody development of Trion Research for technical assistance with sample measurement and Ralph Mocikat from the Helmholtz-Zentrum München for critically reading the manuscript.

Author Contributions PR, HWB and HL designed the study, and PR wrote the paper. PR, AS and CK carried out the data management and analysis. HWB and HL provided study materials or patients. All authors have agreed with the final version of the paper.

Funding Design and conduct of the study, collection, management, analysis, and interpretation of the data, preparation, review and approval of the manuscript by Trion Research GmbH.

Data availability The datasets used and analyzed during the current study are available from the corresponding author on reasonable request.

\section{Declarations}

Conflict of interest Peter Ruf, Claudia Kellermann: Employees of Trion Research GmbH, Am Klopferspitz 19, 82152 Martinsried, Germany. Horst Lindhofer: Shares in Trion Research GmbH, Am Klopferspitz 19, 82152 Martinsried, Germany. Horst Lindhofer, Hartwig W. Bauer: Filed a patent on intravesical usage of multispecific antibodies (PCT/EP2017/057608).

Ethical approval The two patients were treated on a named patient basis with signed informed consent without requirement of ethical approval. Treatment was performed in accordance with the Declaration of Helsinki.

Open Access This article is licensed under a Creative Commons Attribution 4.0 International License, which permits use, sharing, adaptation, distribution and reproduction in any medium or format, as long as you give appropriate credit to the original author(s) and the source, provide a link to the Creative Commons licence, and indicate if changes were made. The images or other third party material in this article are included in the article's Creative Commons licence, unless indicated otherwise in a credit line to the material. If material is not included in the article's Creative Commons licence and your intended use is not permitted by statutory regulation or exceeds the permitted use, you will need to obtain permission directly from the copyright holder. To view a copy of this licence, visit http://creativecommons.org/licenses/by/4.0/.

\section{References}

1. Stewart BW Wild CP. World Cancer Report (2014). International Agency for Research on Cancer, Lyon

2. EAU Guidelines on Non-muscle-invasive Bladder Cancer (TaT1 \& CIS) (2018). Edn. presented at the EAU Annual Congress Copenhagen. ISBN 978-94-92671-01-1

3. Aldousari S, Kassouf W (2010) Update on the management of non-muscle invasive bladder cancer. Can Urol Assoc J 4(1):5664. https://doi.org/10.5489/cuaj.777

4. Boyd LA (2003) Intravesical Bacillus Calmette-Guerin for treating bladder cancer. Urol Nurs 23(3):189-192

5. Decaestecker K, Oosterlinck W (2015) Managing the adverse events of intravesical bacillus Calmette-Guérin therapy. Res Rep Urol 7:157-163. https://doi.org/10.2147/RRU.S63448

6. Spizzo G, Fong D, Wurm M et al (2011) EpCAM expression in primary tumour tissues and metastases: an immunohistochemical analysis. J Clin Pathol 64(5):415-420. https://doi.org/10. 1136/jcp.2011.090274

7. Went PT, Lugli A, Meier S et al (2004) Frequent EpCam protein expression in human carcinomas. Hum Pathol 35(1):122-128. https://doi.org/10.1016/j.humpath.2003.08.026

8. Seimetz D, Lindhofer H, Bokemeyer C (2010) Development and approval of the trifunctional antibody catumaxomab (antiEpCAM x anti-CD3) as a targeted cancer immunotherapy. Cancer Treat Rev 36(6):458-67. https://doi.org/10.1016/j.ctrv.2010. 03.001

9. Chelius D, Ruf P, Gruber P et al (2010) Structural and functional characterization of the trifunctional antibody catumaxomab. MAbs 2(3):309-319. https://doi.org/10.4161/mabs.2.3.11791

10. Zeidler R, Mysliwietz J, Csánady M et al (2000) The Fc-region of a new class of intact bispecific antibody mediates activation of accessory cells and NK cells and induces direct phagocytosis of tumour cells. Br J Cancer 83(2):261-266. https://doi.org/10.1054/ bjoc. 2000.1237

11. Kontermann RE (ed) (2011) Bispecific Antibodies. Springer, Berlin Heidelberg

12. Hess J, Ruf P, Lindhofer H (2012) Cancer therapy with trifunctional antibodies: linking innate and adaptive immunity. Future Oncol 8(1):73-85. https://doi.org/10.2217/fon.11.138

13. Balzar M, Winter MJ, de Boer CJ, Litvinov SV (1999) The biology of the 17-1A antigen (Ep-CAM). J Mol Med (Berl) 77(10):699-712. https://doi.org/10.1007/s001099900038

14. Lewis SA (2000) Everything you wanted to know about the bladder epithelium but were afraid to ask. Am J Physiol Renal Physiol 278(6):F867-F874. https://doi.org/10.1152/ajprenal.2000.278.6. F867 
15. Zorzos J, Skarlos DV, Epenetos AA et al (1993) Intravesical administration of tumor-associated monoclonal antibody AUA1 in transitional cell carcinoma of the bladder: a study of biodistribution. Urol Res 21(6):435-438. https://doi.org/10.1007/BF003 00082

16. Tzeng CC, Liu HS, Li C et al (1996) Characterization of two urothelium cancer cell lines derived from a blackfoot disease endemic area in Taiwan. Anticancer Res 16(4A):1797-1804

17. Jäger M, Schoberth A, Ruf $P$ et al (2012) Immunomonitoring results of a phase II/III study of malignant ascites patients treated with the trifunctional antibody catumaxomab (anti-EpCAM $\mathrm{x}$ anti-CD3). Cancer Res 72(1):24-32. https://doi.org/10.1158/ 0008-5472.CAN-11-2235

18. Ruf P, Gires O, Jäger M, Fellinger K, Atz J, Lindhofer H (2007) Characterisation of the new EpCAM-specific antibody HO-3: implications for trifunctional antibody immunotherapy of cancer. Br J Cancer 97(3):315-321. https://doi.org/10.1038/sj.bjc.66038 81

19. Ruf P, Kluge M, Jäger M et al (2010) Pharmacokinetics, immunogenicity and bioactivity of the therapeutic antibody catumaxomab intraperitoneally administered to cancer patients. Br J Clin Pharmacol 69(6):617-625. https://doi.org/10.1111/j.1365-2125.2010. 03635

20. Heiss MM, Murawa P, Koralewski P et al (2010) The trifunctional antibody catumaxomab for the treatment of malignant ascites due to epithelial cancer: Results of a prospective randomized phase II/ III trial. Int J Cancer 127(9):2209-2221. https://doi.org/10.1002/ ijc. 25423

21. Sebastian M, Passlick B, Friccius-Quecke H et al (2007) Treatment of non-small cell lung cancer patients with the trifunctional monoclonal antibody catumaxomab (anti-EpCAM x anti-CD3): a phase I study. Cancer Immunol Immunother 56(10):1637-44. https://doi.org/10.1007/s00262-007-0310-7

22. Rosenberg JE, Hoffman-Censits J, Powles T et al (2016) Atezolizumab in patients with locally advanced and metastatic urothelial carcinoma who have progressed following treatment with platinum-based chemotherapy: a single-arm, multicentre, phase 2 trial. Lancet 387(10031):1909-1920. https://doi.org/10.1016/ S0140-6736(16)00561-4

23. Stenehjem DD, Tran D, Nkrumah MA, Gupta S (2018) PD1/PDL1 inhibitors for the treatment of advanced urothelial bladder cancer.
Onco Targets Ther 11:5973-5989. https://doi.org/10.2147/OTT. S135157

24. Massard C, Gordon MS, Sharma S et al (2016) Safety and efficacy of durvalumab (Medi4736), an anti-programmed cell death ligand-1 immune checkpoint inhibitor, in patients with advanced urothelial bladder cancer. J Clin Oncol 34(26):3119-3125. https:// doi.org/10.1200/JCO.2016.67.9761

25. Burger M, Catto JW, Dalbagni G et al (2013) Epidemiology and risk factors of urothelial bladder cancer. Eur Urol 63(2):234-241. https://doi.org/10.1016/j.eururo.2012.07.033

26. Han RF, Pan JG (2006) Can intravesical bacillus Calmette-Guérin reduce recurrence in patients with superficial bladder cancer? A meta-analysis of randomized trials. Urology 67(6):1216-1223. https://doi.org/10.1016/j.urology.2005.12.014

27. Shelley MD, Wilt TJ, Court J, Coles B, Kynaston H, Mason MD (2004) Intravesical bacillus Calmette-Guérin is superior to mitomycin $\mathrm{C}$ in reducing tumour recurrence in high-risk superficial bladder cancer: a meta-analysis of randomized trials. BJU Int 93(4):485-490. https://doi.org/10.1111/j.1464-410x.2003.04655

28. Böhle A, Jocham D, Bock PR (2003) Intravesical bacillus Calmette-Guerin versus mitomycin $\mathrm{C}$ for superficial bladder cancer: a formal meta-analysis of comparative studies on recurrence and toxicity. J Urol 169(1):90-95. https://doi.org/10.1097/01.ju.00000 39680.90768

29. Zlotta AR, Fleshner NE, Jewett MA (2009) The management of BCG failure in non-muscle-invasive bladder cancer: an update. Can Urol Assoc J 3(6 Suppl 4):S199-S205. https://doi.org/10. 5489/cuaj.1196

30. Burges A, Wimberger P, Kümper C et al (2007) Effective relief of malignant ascites in patients with advanced ovarian cancer by a trifunctional anti-EpCAM $\mathrm{x}$ anti-CD3 antibody: a phase I/II study. Clin Cancer Res 13(13):3899-3905. https://doi.org/10.1158/10780432.CCR-06-2769

Publisher's Note Springer Nature remains neutral with regard to jurisdictional claims in published maps and institutional affiliations. 